This document was prepared in conjunction with work accomplished under Contract No. DE-AC09-96SR18500 with the U. S. Department of Energy.

\title{
DISCLAIMER
}

This report was prepared as an account of work sponsored by an agency of the United States Government. Neither the United States Government nor any agency thereof, nor any of their employees, makes any warranty, express or implied, or assumes any legal liability or responsibility for the accuracy, completeness, or usefulness of any information, apparatus, product or process disclosed, or represents that its use would not infringe privately owned rights. Reference herein to any specific commercial product, process or service by trade name, trademark, manufacturer, or otherwise does not necessarily constitute or imply its endorsement, recommendation, or favoring by the United States Government or any agency thereof. The views and opinions of authors expressed herein do not necessarily state or reflect those of the United States Government or any agency thereof.

This report has been reproduced directly from the best available copy.

Available for sale to the public, in paper, from: U.S. Department of Commerce, National Technical Information Service, 5285 Port Royal Road, Springfield, VA 22161, phone: (800) 553-6847, fax: (703) 605-6900

email: orders@ntis.fedworld.gov

online ordering: http://www.ntis.gov/help/index.asp

Available electronically at http://www.osti.gov/bridge

Available for a processing fee to U.S. Department of Energy and its contractors, in paper, from: U.S. Department of Energy, Office of Scientific and Technical Information, P.O. Box 62, Oak Ridge, TN 37831-0062,

phone: (865)576-8401,

fax: (865)576-5728

email: $\underline{\text { reports@ adonis.osti.gov }}$ 
WSRC-TR-2003-00029

REVISION: 0

KEYWORDS:

Dilution

Flow

Hydrogen

Dissolver

\section{HB-LINE DISSOLVER DILUTION FLOWS AND DISSOLUTION CAPABILITY WITH DISSOLVER CHARGE CHUTE COVER OFF(U)}

January 15, 2003

\section{TABLE OF CONTENTS}

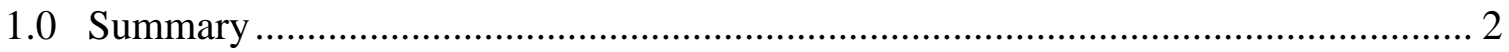

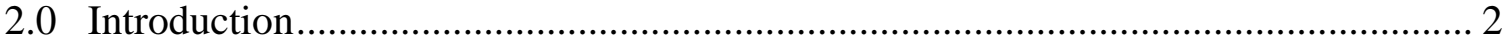

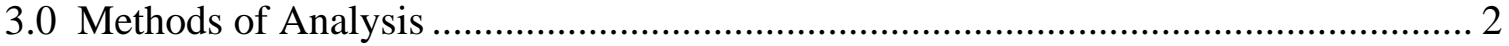

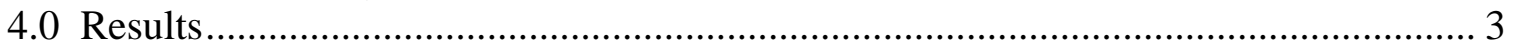

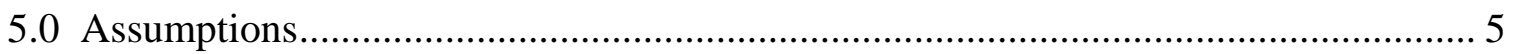

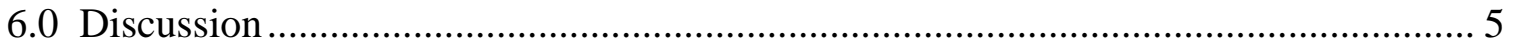

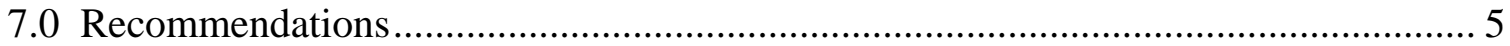

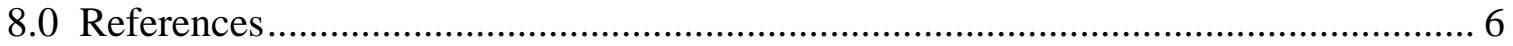




\subsection{Summary}

A flow test was performed in Scrap Recovery of HB-Line to document the flow available for hydrogen dilution in the dissolvers when the charge chute covers are removed. Air flow through the dissolver charge chutes, with the covers off, was measured. A conservative estimate of experimental uncertainty (33\%) was subtracted from the results. After subtraction, the test showed that there is 20 cubic feet per minute (cfm) air flow through the dissolvers during dissolution with a glovebox exhaust fan operating, even with the scrubber not operating. This test also showed there is $6.6 \mathrm{cfm}$ air flow through the dissolvers (after subtraction of experimental uncertainty) if the scrubber and the glovebox exhaust fans are not operating. Three H-Canyon exhaust fans provide sufficient motive force to give this $6.6 \mathrm{cfm}$ flow. Material charged to the dissolver will be limited to chemical hydrogen generation rates that will be $\leq 25 \%$ of the Lower Flammability Limit (LFL) during normal operations. The H-Canyon fans will maintain hydrogen below LFL if electrical power is lost. No modifications are needed in HB-Line Scrap Recovery to ensure hydrogen is maintained less than LFL if the scrubber and glovebox exhaust fans are not operating.

\subsection{Introduction}

Radioactive scrap is dissolved in HB-Line Scrap Recovery. Some of this scrap contains material that generates hydrogen during dissolution in nitric acid. This hydrogen is diluted with air pulled through an opening in the dissolver charge chute cover by the HBLine vessel vent system. To meet NFPA-69 requirements (Reference 1), the hydrogen concentration in the dissolver vapor spaces must be maintained less than or equal to $25 \%$ of the LFL during dissolution. The LFL of hydrogen in air is $4 \%$ by volume.

Some material that may generate chemical hydrogen at concentrations greater than LFL must be dissolved in HB-Line to meet site missions. More flow will be needed for hydrogen dilution than is now available, and the time to reach LFL is much shorter than for material currently being dissolved. It is desirable to avoid costs of physical modifications for this short campaign, if practical. A flow test was performed with the dissolver charge chute covers removed, to determine the flow available with minimal flow resistance in the dissolver charge chute. Also, flow was measured with the glovebox exhaust system fans off and the scrubber off. The motive force for drawing air through the dissolvers, during this condition, was the H-Canyon exhaust fans. The results of these tests are documented in Reference 2.

\subsection{Methods of Analysis}

The average flow rate through the dissolver charge chute when a glovebox exhaust fan is operating, but with the scrubber not operating, was measured at $30 \mathrm{cfm}$ (Reference 2). This was an average of readings for both dissolvers (RD-13 and RD-14) with several 
points being measured across the cross-sectional area of each dissolver charge chute. Measurement conditions are stated as atmospheric pressure and $72{ }^{\circ} \mathrm{F}$.

The average flow rate through the dissolver charge chute when the glovebox exhaust fans and the scrubber are not operating (simulating a loss of glovebox exhaust fans and scrubbers in HB-Line) is $10 \mathrm{cfm}$ (Reference 2).

All the measurements were made for a single set of experimental conditions. An experimental uncertainty cannot be analytically calculated for the results with only a single run for each set of conditions. The data in Reference 2 was examined. The instrument used for the measurements has an uncertainty of $2 \%$. Further, experimental uncertainty is decreased when the results are derived from the average of measurements at several points, rather than when a single measurement is made. The flow values in Reference 2 are from multiple flow measurements. An experimental uncertainty of $\pm 33 \%$ is considered conservative for this data set. This covers possible small variations in flow between the two glovebox exhaust fans, cell cover status in H-Canyon, slight variations in glovebox pressure during operation, and other factors of this type. The experimental results will be decreased by $33 \%$ to determine the hydrogen production rate that can be kept within limits.

The pressure inside the gloveboxes is less than room pressure when the glovebox exhaust fans are operating, typically by 0.6 inches water gage (WG). The pressure inside the glovebox is closer to room pressure, but still may be less than room pressure, when the scrubber and glovebox exhaust fans are not operating. Flow was measured at the charge chute opening, which is essentially glovebox pressure. For purposes of calculating allowable chemical hydrogen production rates, laboratory data documenting chemical hydrogen production rates will be reduced to one atmosphere and $72{ }^{\circ} \mathrm{F}$ for comparison to the purge air flow rate. This introduces potential differences of less than $0.2 \%$ between probable glovebox conditions when the measurements were made and atmospheric pressure, and is well within the experimental uncertainty applied to these measurements.

\subsection{Results}

The following equation (equation 3 from Reference 3 ) relates the equilibrium hydrogen concentration to the purge flow rate. The purge flow units and hydrogen generation units have been switched from cubic feet per hour (cfh) to $\mathrm{cfm}$ to reflect the larger dilution flows measured through the dissolver with the charge chute cover off.

$\mathrm{C}(\mathrm{H} 2)=\mathrm{F}(\mathrm{H} 2) /[\mathrm{F}(\mathrm{P})+(\mathrm{F}(\mathrm{H} 2) / \mathrm{X}(\mathrm{H} 2))]$

Eq. 1.

Where:

$\mathrm{C}(\mathrm{H} 2)=$ hydrogen volume fraction in purged space 
$\mathrm{F}(\mathrm{H} 2)=$ hydrogen generation rate, $\mathrm{cfm}$ at $72^{\circ} \mathrm{F}$ and atmospheric pressure

$\mathrm{F}(\mathrm{P})=$ purge rate of air, $\mathrm{cfm}$ at atmospheric pressure and $72^{\circ} \mathrm{F}$

$\mathrm{X}(\mathrm{H} 2)=$ fraction of hydrogen in gases

For normal operations, $\mathrm{C}(\mathrm{H} 2)$ is 0.01 . This meets NFPA requirements (Reference 1).

$\mathrm{X}(\mathrm{H} 2)$ is conservatively set to 1.0 for this evaluation.

The amount of dilution flow, when adjusted for the assumed experimental uncertainty, is $(0.66)(30)=20 \mathrm{cfm}$.

Equation 1 is solved for $\mathrm{F}(\mathrm{H} 2)$ under these conditions. The resulting hydrogen generation rate that can be maintained at $\leq 25 \%$ of LFL is $0.202 \mathrm{cfm}$ at $72{ }^{\circ} \mathrm{F}$ and one atmosphere.

An engineered evaluation based on the hydrogen generation properties of the material to be dissolved is required before Mixed Scrap is charged to the dissolver. The evaluation above assumed the hydrogen volume fraction in the chemically-generated gases is 1.0. Slightly higher hydrogen generation rates than stated above can be diluted if the hydrogen concentration is less than 1.0, as seen from Equation 1. This will be evaluated in the individual engineering evaluations for the material charged.

If the glovebox exhaust fans and scrubbers are not operating, the H-Canyon exhaust fans will supply the motive force for hydrogen purge. The purge rate from Reference 2 is 10 $\mathrm{cfm}$. This is adjusted to $(0.66)(10)=6.6 \mathrm{cfm}$ to conservatively account for experimental uncertainty, as discussed above. Equation 1 is used to evaluate the resulting hydrogen concentration for this upset conditions, using $0.202 \mathrm{cfm}$ for the hydrogen generation rate. The resulting concentration is 0.03 , or $3 \%$. This is still less than LFL, so the motive force from the H-Canyon fans is sufficient to maintain the chemical hydrogen concentration at less than LFL for a simulated loss of power in HB-Line.

The air flow rate through the charge chute will be less than $6.6 \mathrm{cfm}$, if the dissolver solution is boiling when the glovebox exhaust fans are lost. When boiling, steam and nitric acid vapors are being injected into the glovebox atmosphere from the solution. Flow of these vapors up the vessel vent piping decreases the amount of air that will be pulled through the charge chute. These vapors will provide an inerting atmosphere and maintain hydrogen $\leq$ LFL until boiling ceases. Dissolver cooldown data demonstrates the dissolver drops a full degree Centigrade in temperature in three minutes after the heater is cut off. Boiling will cease when the heater temperature drops to the boiling temperature. At this point, the driving force for heat transfer is lost. This will occur before the temperature in the solution has dropped. Once steam and nitric acid vapor generation ceases (in significantly less than the three minutes it takes the temperature to drop a degree), the H-Canyon fans draw sufficient air through the charge chute to dilute the hydrogen to less than LFL. 
In the past, it has been assumed that operator action was needed to restore dilution flow if purge flow was lost. The amount of time the operator had to accomplish this action was specified in DSA documents. This test has demonstrated that the H-Canyon exhaust fans provide sufficient motive force to keep the hydrogen concentration less than LFL, if the glovebox exhaust fans are lost. Since no operator action is needed to maintain hydrogen less than LFL if the glovebox exhaust fans are lost, a response time is not applicable.

\subsection{Assumptions}

An experimental uncertainty of $33 \%$ is assumed when evaluating the flow data taken in Reference 2. This uncertainty is applied since the data is used to establish conditions to prevent an energetic event. By design, the flow rate through the two dissolvers, with the charge chute covers removed, should be the same. This is true when the motive force for air drawn through the chutes is the vessel vent system or the H-Canyon exhaust fans. Therefore, the flow rate established in Reference 2 is treated as an average of two readings. Further, the value for the flow through each individual dissolver charge chute is the result of five separate measurements per dissolver. This provides a more robust measurement of the flow than if a single measurement had been made for each dissolver.

Further, the flow for the normal case was made with the scrubber off. This provides additional conservatism for the flow assumed for normal dissolution.

The assumed uncertainty of $33 \%$ is conservative for the procedure used to measure the flow.

\subsection{Discussion}

The dissolvers are currently operated with the charge chute covers installed during dissolution. This is to ensure that nitric acid fumes do not migrate back into the glovebox and degrade optical surfaces during operation. The air flow rates measured with the charge chute cover off indicate all the fumes will be contained within the dissolver. The risk of significant optical surface degradation, for the relatively short campaign planned with the charge chute covers off, is considered acceptably low.

\subsection{Recommendations}

For the engineered evaluation performed before Mixed Scrap is dissolved, assume a charger dilution flow of $\leq 20 \mathrm{cfm}$ at $72{ }^{\circ} \mathrm{F}$ and one atmosphere when evaluating the amount of material allowed in a dissolver charge when operating with the dissolver charge chute cover off. This will ensure the hydrogen concentration is $\leq 25 \%$ LFL during dissolution. 
For the engineered evaluation performed before Mixed Scrap is dissolved, confirm (by calculation) that a dilution flow of $6.6 \mathrm{cfm}$ at one atmosphere and $72{ }^{\circ} \mathrm{F}$ will maintain the hydrogen concentration less than $4 \%$ by volume (LFL) for the dissolver charge calculated above when operating with the dissolver charge chute cover off and a loss of the glovebox exhaust fans and the scrubbers. This will ensure the hydrogen is less than LFL if these conditions occur.

\subsection{References}

1.0 NFPA-69, Standard on Explosion Prevention System, 1997

2.0 WSRC-TR-2003-00028, HB-Line Dissolver Air Flow Test (U), January 8, 2003

3.0 N-CLC-H-00454, Rev. 4, Hydrogen Control During Phase II Operations With 50 Grams of Plutonium per Liter, 9/3/02 